Egyptian Journal of Aquatic Biology \& Fisheries

Zoology Department, Faculty of Science,

Ain Shams University, Cairo, Egypt.

ISSN $1110-6131$

Vol. 25(4): 313 - 327 (2021)

www.ejabf.journals.ekb.eg

\title{
Reproductive Biology of the Silver Hatchet Chela cachius (Hamilton 1822) in a
} Perennial Water Body in Bangladesh.

\section{Md. Nowsher Ali ${ }^{1}$, Shyamal Kumar Paul ${ }^{2,4^{*}}$, Zoarder Faruque Ahmed ${ }^{3}$, Debasish Saha ${ }^{2}$, Mst. Kaniz Fatema ${ }^{3}$ and Priyanka Rani Majumdar ${ }^{2}$}

1.Department of Fisheries, Matshyabhaban, Peoples Republic of Bangladesh, Dhaka, Bangladesh

2.Department of Fisheries and Marine Science, Noakhali Science and Technology University,

Noakhali, Bangladesh.

3.Department of Fisheries Management, Bangladesh Agricultural University, Mymensingh,

Bangladesh.

4. Research Cell, Noakhali Science and Technology University, Noakhali, Bangladesh.

"Corresponding Author: shyamal@nstu.edu.bd

\section{ARTICLE INFO}

Article History:

Received: Jan. 3, 2021

Accepted: June 19, 2021

Online: Aug. 9, 2021

Keywords:

Chela cachius,

Gonadosomatic

index,

Spawning stages,

Fecundity.

\section{ABSTRACT}

The reproductive biology of the silver hatchet chela, Chela cachius, was addressed in the present study. A total of 1200 specimens were caught by fine meshed seine nets from a large perennial water body in Bangladesh Agricultural University Campus, Mymensingh. The gonadosomatic index and the histological examination suggested that the spawning seasons of C. cachius were from February to May and from July to September. Based on histological examination, nine stages of oocyte development were determined; namely, early perinucleolus, late perinucleolus, yolk vesicle, primary yolk, secondary yolk, tertiary yolk, migratory nucleus, premature and mature stage. The absence of postovulatory follicle and hydrated eggs and the presence of two modes of eggs in the mature ovaries indicated that $C$. cachius was a single spawner, and its spawning frequency or strategy was a synchronous type. The average fecundity was $1708 \pm 838.86$ having a standard length of $49 \pm 2.89 \mathrm{~mm}$ in the first season (February to May) and 1997.33 \pm 889.92 , whereas the standard length was $46.66 \pm 1.53 \mathrm{~mm}$ in the second season (from July to September). The findings of the present study might be helpful for induced breeding of the species for commercial purposes as well as for management of the natural population (banning/restriction of fishing during spawning season) of $C$. cachius.

\section{INTRODUCTION}

Chela cachius (Hamilton 1822) is one of the cyprinid fishes under the family Cyprinidae, commonly available in rivers, canals, beels, haors, ponds, ditches, floodplains, oxbow lakes, man-made reservoirs lakes etc. in Bangladesh, India, Pakistan, Nepal and Myanmar (Hossain \& Wahab, 2010). The common name of this fish is silver hatchet chela and is locally known as chhep chela in Bangladesh. This is one of the most common, small-sized fishes caught in large 
quantities from various freshwater habitats. It breeds freely in ponds, tanks and small streams and possesses potentiality as a larvicidal fish. Morphologically, the body of 'chhep chela' is deep and greatly compressed. The abdomen is keeled only between and behind the pelvic fins. The mouth is slightly oblique, cleft and not extending to below the anterior edge of eye.

In Bangladesh, little biological information on the biology of inland fishes is available, including most of the commercially important species. Moreover, there is an urgent need to manage and regulate the small-scale inland capture fishery in the region, which requires basic population dynamics information for the targeted species (Santos et al., 1995). For the assessment and management of fish stocks, temporal changes of number and weight in stock should be studied. Spawning biology is the initial point of those changes. Reproduction in fishes is the process by which species is perpetuated and by which in combination with genetic change, characteristics for new species appear (Cech et al., 2012).

At present, the development of a management plan is difficult due to the lack of adequate information of the basic biology i.e., the reproductive biology of fish. Successful reproduction is obviously a prerequisite for a good recruitment. Reproduction is highly variable in most fishes and can be stabilized to some extent only by maintaining reasonably large spawning stock. Moreover, knowledge on reproductive biology of fish is essential for evaluating the commercial potentialities of its stock, life history, culture practice and management of its fishery (Jasmine \& Molina, 2016). Reproductive potential of a population is one of the basic exigencies to designate the individuals of that population in respect to their gonadal conditions (Mojumder et al., 2020). In order to achieve success in fish culture, it is important to assess the yearly spawning cycle of cultivable fishes. Spawning cycle or reproductive cycle helps to understand the reproductive biology of culturable fish species and leads to regulate its proper management measures (Tan-Fermin et al., 1997). Identification of the spawning activity of an exploited fish species provides management options for the protection of its natural stocks (Mondol et al., 2019). Information of gonadal development and the spawning season of a species make subsequent studies on spawning frequency of its population easier, which is important for its management. Another important phenomenon for the reproductive biology of fish species is fecundity estimation. Fecundity is one of the important aspects of fish biology and fish population dynamics, which should be understood to explain variations in the level of production as well as to make efforts to increase the amount of harvest (Rahman \& Tachihara, 2005). In addition, fecundity is one of the most important aspect of fish biology which must be understood to explain variations in the level of production, induced breeding success and amount of harvest. It may be expressed 
in terms of the number of produced per brood fish in a breeding season (Ahmed $\boldsymbol{e t}$ al., 2012). Knowledge on the fecundity of a fish species is important for determining (a) the effects of environmental factors (Ahmed et al., 2011) (b) fluctuation in the egg production potential of individual stock related to life process such as age and growth (Ahmed $\boldsymbol{e}$ al., 2012) (c) commercial management of fishery (Divipala $\boldsymbol{e t}$ al., 2013) and spawning potential and its success (Saha $\boldsymbol{e t}$ al., 2021). Knowledge on the state of maturity of individuals in a population is useful and the estimation of annual egg production of a fish is considerably important in studies of population dynamics to understand recruitment and manage populations properly and effectively (Chakraborty et al., 2010; Mondol et al., 2019).

Life history characteristics, which include size at sexual maturity and the reproductive life span may differ according to populations (Ahmed et al., 2012). Other life history characteristics i.e., reproductive characteristics, fecundity, spawning season and frequency of maturation or maturity stages and oocyte formation (Akter $\boldsymbol{e t}$ al., 2019) also differ with populations. The spawning season of female depends on the quantity of eggs and the number of spawning. (Chakraborty et al., 2010). Notably, the spawning frequency is the fraction of daily spawning (Divipala et al., 2013). The term first maturity is used to describe a fish spawning for the first time and the mean length at first reproduction describes the length at which fitly percent of all female fish have ovaries in an advanced stage of development. Maturity stages refer to the degree of ripeness (how close the fish to its spawning time) of the ovaries and testes of a fish (Saha et al., 2021).

Oocyte formation in teleost fish is a dynamic process that exhibits diversity in oocyte developmental patterns among species (Mondol et al., 2019). The process of oocyte formation has been generally categorized as synchronous, group synchronous and asynchronous (Lubzens et al., 2010). Most of the teleosts determine their time reproduction with respect to environmental factors. An egg is the final product of oocyte growth and differentiation. Spawning depends on the oocyte development of fish (Lubzens et al., 2010). Therefore, spawning period is the crucial subject of the life traits of fish and can be beneficial information for conservation and protection of fish in the natural habitats. Generally, spawning occurs during a particular phase of the reproductive cycle. Some breed once annually (single spawner), while others breed at regular intervals throughout the year (Saha et al., 2021). Therefore, a sound knowledge of the natural spawning cycle of a species is essential for planning various aquaculture operations. Since the middle of the $19^{\text {th }}$ century, various researchers have conducted studies on teleostean gonads (Lubzens et al., 2010). Nevertheless, the cyclic changes in the gonads have only been examined in a few dozen species (Mondol et al., 2019). 
Remarkably, the economic and the nutritional importance of this fish species to the rural and urban people and to the fishing community as well is enormous. However, adequate studies on their reproductive biology, namely oocyte development, spawning season and its frequency, fecundity, minimum length at maturity and mean length at first reproduction are almost unknown without which its appropriate management is impossible. Therefore, it is urgently necessary to take appropriate measures to conserve these endangered fish species by knowing their biology, improving their habitats, and thereby recommending appropriate management measures.

\section{MATERIALS AND METHODS}

\section{Study site}

One L shaped pond, with one hector surface area and one meter water depth, was used for the present study. The target species, C. cachius, were stocked with 250 ind./decimal. The average weight and length of each were $1.23 \pm 0.36 \mathrm{~g}$ and $20 \pm 3.69 \mathrm{~mm}$, respectively. The water body under the present investigation is located at the Field Laboratory, Faculty of Fisheries, Bangladesh Agricultural University, Mymensingh, Bangladesh. Mymensingh, a northeastern district of Bangladesh, lying between latitude $23^{\circ} 58^{\prime}$ and $25^{\circ} 25^{\prime} \mathrm{N}$, and longitude $89^{\circ} 38^{\prime}$ and $91^{\circ} 15^{\prime} \mathrm{E}$. The average elevation of the area is 11.59 meter above the sea level.

\section{Fish Sampling}

Fish was sampled once a month by using a fine meshed seine net and a cast net to harvest all size groups of chela population. At each sampling, emphasis was given to ensure the collection of at least 100 individuals. Samples were collected randomly and preserved immediately with $10 \%$ neutralized formalin in small plastic containers to avoid decomposition.

\section{Measurement of length and weight}

The standard length (SL) was measured from the tip of the snout (mouth closed) to the hind margin of the hypural bone of the tail usually located by the position of a crease when the tail was a little bent. The whole fish was measured as body weight (BW). SL was measured to the nearest $\mathrm{mm}$ in a measuring board. The BW was taken to the nearest $\pm 0.01 \mathrm{~g}$ using an electric digital balance (Shimadzu UX320G).

\section{Collection of gonad and sex determination}

The abdomens of fish samples were cut open by scissors, and gonads were removed with blunt forceps carefully. Muscles, fat tissues, digestive organs and blood veins were properly removed. Fish were identified as male and female by observing the gonads with the naked eye. Both left and right gonads were measured together as gonad 
weight to the nearest $0.001 \mathrm{~g}$. Eventually, these were preserved with $10 \%$ formalin in small vials.

\section{Gonadosomatic index (GSI)}

A gonadosomatic index (GSI) is often used to follow the reproductive cycle of a species over the year at monthly intervals or lesser than that. This index which assumes that a gonad increases in size with increasing development compares the mass of the gonad (GW) with the total mass of the animal (BW). The GSI of each fish specimen in the study was calculated as GSI $=(\mathrm{GW} / \mathrm{BW}) * 100$ (Afonso-Dias et al., 2005).

\section{Histological examination}

Ovaries were preserved with $10 \%$ buffer formalin solution for further study. Development of ovaries were tested by the conventional histological process. A transverse segment of about $3 \mathrm{~mm}$ thick from the middle part ovary was taken, then dehydration of ovarian segment was formed by the passage of tissue piece through a series of ethyl alcohol solutions in the room temperature. The impregnation of tissue was carried out with benzene, and a solvent paraffin was applied twice for 1 hour, infiltrated in automatic tissue processor (SHANDON, CITADEL 1000) and then melted paraffin at $60{ }^{\circ} \mathrm{C}$. Then, the segmentation of ovary was performed in a clay mold with melted paraffin for embedment, and paraffin block was cut to serial sections of $5 \mu \mathrm{m}$ each using a microtome (micro Tech 4050). The slides mounted with gonadal sections were stained by hematoxylin and eosin. Finally, Canada balsam; a mounting medium was applied and cover slip was lowered with place, and the sections were examined under light microscope (OLYMPUS, Model CHS, Japan).

\section{Length at sexual maturity}

Females classified into various spawning stages by ovarian histology were used to determine minimum length at sexual maturity and mean length at first spawning. For the determination of minimum length at maturity, standard length and GSI values of all female specimens were plotted, and female with the lowest standard length having final spawning stage was considered capable of spawning and its standard length was the minimum standard length at maturity of the population. For the determination of mean standard length at first reproduction, a large sample was collected in the month when peak spawning occurred. The developmental stages of all individual females were examined histologically. The logistic model was fitted to the proportion of individuals; having the most advanced gonadal developmental stage by each standard length class. The mean standard length at first reproduction was estimated at which 50 percent of all female fish have ovaries in the most advanced stage of development.

\section{Fecundity estimation}

Fecundity, defined as the number of oocytes released by a female in a spawning season, was estimated gravimetrically. Prior to estimation; oocytes from samples of 0.001

$\mathrm{g}$ were obtained from three portions (anterior, middle and posterior) of five ovarian lobes and were randomly counted and measured to determine the existence of significant 
differences between locations. All the eggs were separated from each other with needles and measured along their longest axis under stereomicroscope. The number of eggs in the largest modal group b was summed. Fecundity $(\mathrm{F})$ was calculated using the formula $\mathrm{F}=$ $\mathrm{GW}^{*}(\mathrm{~b} / \mathrm{gw})$ (Afonso-Dias et al., 2005).

\section{RESULTS}

\section{Standard length (SL) and body weight of $C$. cachius}

In total, 1200 specimens were captured over the study period, of which the number of male and female were 608 and 592, respectively. The SL of male and female ranged from $30-61 \mathrm{~mm}$ and 31-63 mm, while the body weight ranged from 0.26 to $2.76 \mathrm{~g}$ and from 0.28 to $3.47 \mathrm{~g}$, respectively (Table 1 ).

\section{Determination of spawning season of $C$. cachius}

Male and female fishes maintained high levels of mean GSI during July to September with the exception of June. The GSI of female started to increase in February (5.42 \pm 2.34$)$ with a recorded peak in July $(11.76 \pm 3.59)$ while it started to decrease in May $(7.77 \pm 2.65)$ and a sudden decrease in June (4.21 \pm 1.22$)$. An increasing and decreasing patterns of the GSI values were noted from July to September. But, the GSI declined sharply during October to February. The GSI values of both males and females showed two peaks; one in April (8.94 \pm 2.41$)$ and July (11.76 \pm 3.59$)$ and the other in September (9.41 \pm 3.14$)$. The highest GSI value in both sexes occurred in July (male: $3.8 \pm 1.32$, Female: 11.76 \pm 3.59 ) and decreased as spawning progressed. These data suggested that two spawning peaks occurred; one during February to May and another one during July to September (Table$2)$. The GSI value of male had no significant difference $(p>0.01)$ between the month of March, April or July and on the other hand, July and September for female.

\section{Frequency occurrence of ovarian stages}

For the ovarian development, immature ovaries were not found in the months of April or July. Developing ovaries were observed in every month with different percentage except for May and November. Maturing ovaries were found from February to September except in June, and the highest percentage (44.1\%) was in August. Spawning ovaries were observed from February to May and July to September, with the highest percentage $(55.25 \%)$ in July. Female of mature ovaries were considered those spawning or near to spawn. The occurrence of spawning ovaries began to appear in February and continued up to September except in June. Occurrence of spawning ovaries started to increase in February, peaked in April and decreased in May and again suddenly decreased in June. Then, it peaked in July and steadily declined in September. After that, its appearance was not found from October to January. This observation confirms that two spawning peaks occurred; one from February to May and another from July to September. 
Table 1. Collection record of Chhep chela, C.cachius from the perennial pond

\begin{tabular}{|c|c|c|c|c|c|c|c|}
\hline \multirow[b]{2}{*}{ 들 } & \multirow[b]{2}{*}{ 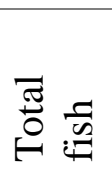 } & \multirow[b]{2}{*}{$\stackrel{4}{\dot{0}} \frac{0}{\tilde{z}}$} & \multicolumn{2}{|c|}{ Size range-Male } & \multirow[b]{2}{*}{ 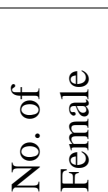 } & \multicolumn{2}{|c|}{ Size range-Female } \\
\hline & & & $\begin{array}{c}\mathrm{SL}^{1} \\
(\mathrm{~mm})\end{array}$ & $\mathrm{BW}^{2}(\mathrm{~g})$ & & $\mathrm{SL}^{1}(\mathrm{~mm})$ & $\mathrm{BW}^{2}(\mathrm{~g})$ \\
\hline January & 100 & 42 & $30-59$ & $0.26-2.55$ & 58 & $37-61$ & $0.56-2.83$ \\
\hline February & 100 & 40 & $35-58$ & $0.57-2.56$ & 60 & $36-63$ & $0.58-3.47$ \\
\hline March & 100 & 46 & $31-55$ & $0.35-2.14$ & 54 & $31-60$ & $0.28-2.63$ \\
\hline April & 100 & 50 & $37-61$ & $0.62-2.76$ & 50 & $43-60$ & $1.14-2.47$ \\
\hline May & 100 & 50 & $34-54$ & $0.47-2.21$ & 50 & $40-57$ & $0.75-2.16$ \\
\hline June & 100 & 53 & $33-57$ & $0.39-2.06$ & 47 & $36-60$ & $0.62-2.31$ \\
\hline July & 100 & 55 & $32-56$ & $0.30-2.35$ & 45 & $37-57$ & $0.56-2.07$ \\
\hline August & 100 & 55 & $30-50$ & $0.30-1.59$ & 45 & $35-55$ & $0.43-2.10$ \\
\hline September & 100 & 55 & $33-57$ & $0.39-2.02$ & 45 & $36-60$ & $0.56-2.52$ \\
\hline October & 100 & 54 & $36-60$ & $0.55-2.03$ & 46 & $43-60$ & $0.91-2.39$ \\
\hline November & 100 & 55 & $34-49$ & $0.50-1.55$ & 45 & $37-58$ & $0.53-2.48$ \\
\hline December & 100 & 53 & $33-52$ & $0.38-2.08$ & 47 & $32-61$ & $0.35-3.11$ \\
\hline
\end{tabular}

\section{$\mathrm{SL}^{1}$ : Standard length $; \mathrm{BW}^{2}$ : Body weight}

\section{Gonadal histology}

According to the histological observation of ovaries in C. cachius, the maturity stages were as follows: the early perinucleolus stage (EP) in which the oocytes had cytoplasm and nucleoli stained deeply with hematoxylin (basophilic). Nucleus was not basophilic. Several peripheral nucleoli were seen in the inner surface of the nucleus spindle shaped (Fig. 1a).

The late perinucleolus stage (LP) in which the nucleus tends to locate the center of the oocytes. The cytoplasm lost its basophilic property and stained lightly by haematoxylin. Nucleoli were round or spindle shaped and found in the periphery of the nucleus (Fig.1b.). The yolk vesicle stage (YV): Oocytes became bigger and less basophilic but still stained with haematoxylin. White yolk vesicles started to appear initially in the outer part of the cytoplasm, and gradually increased in size and number situated randomly in the cytoplasm, in the middle part or surrounding the nucleus (Fig. 1c). The primary yolk stage (PY) in which small and spherical yolk globule began to appear among yolk vesicles in the peripheral region of cytoplasm (Fig. 1d). The secondary yolk stage (SY) where the yolk globule occupied more than half of the cytoplasm (Fig. 1e). The tertiary yolk stage (TY): The yolk globules increased in size and oil droplets appeared within the cytoplasm (Fig. 1f). The migratory nucleus stage $(\mathrm{MN})$; the nucleus progressively migrated toward the animal pole of the oocyte due to the resumption of the meiosis. Oil droplets coalesced in orate, often as big as the nucleus 
itself or even more sometimes and situated in the inner part of the cytoplasm. Yolk globules started to fuse one to each other too, being gradually bigger and less acidophilic (Fig. 1g). The premature stage (PM); after the nucleus migration, nuclear membrane broke down (germinal vesicle breakdown). Yolk globules coalesced and no nucleus was observed, although the follicle layer was still visible (Fig. 1h). The mature stage (M); Complete vision of yolk Globules was seen together with an overall increase in oocyte translucency (hydrated oocyte). Follicular layer became flattened (Fig. 1i).

Table 2. Monthly gonadosomatic index of male and female C. cachius

\begin{tabular}{lcccccc}
\hline Month & $\begin{array}{l}\text { Examined } \\
\text { Male }\end{array}$ & GSI range & Mean GSI & $\begin{array}{l}\text { Examined } \\
\text { Female }\end{array}$ & GSI range & Mean GSI \\
\hline January & 42 & $0.98-10.51$ & $2.21 \pm 1.32^{\mathrm{cd}}$ & 58 & $1.10-8.36$ & $3.49 \pm 1.27^{\mathrm{d}}$ \\
\hline February & 40 & $0.85-9.59$ & $3.17 \pm 0.98^{\mathrm{bc}}$ & 60 & $1.06-14.57$ & $5.42 \pm 2.34^{\mathrm{c}}$ \\
\hline March & 46 & $0.80-11.13$ & $3.67 \pm 1.06^{\mathrm{a}}$ & 54 & $0.66-23.45$ & $6.87 \pm 1.83^{\mathrm{bc}}$ \\
\hline April & 50 & $0.63-4.28$ & $3.51 \pm 1.61^{\mathrm{a}}$ & 50 & $3.98-12.24$ & $8.94 \pm 2.41^{\mathrm{b}}$ \\
\hline May & 50 & $1.10-4.49$ & $2.61 \pm 1.22^{\mathrm{c}}$ & 50 & $1.73-17.95$ & $7.77 \pm 2.65^{\mathrm{b}}$ \\
\hline June & 53 & $0.85-8.08$ & $1.44 \pm 0.48^{\mathrm{d}}$ & 47 & $0.98-15.14$ & $4.21 \pm 1.22^{\mathrm{d}}$ \\
\hline July & 55 & $1.21-11.12$ & $3.80 \pm 1.32^{\mathrm{a}}$ & 45 & $6.43-18.23$ & $11.76 \pm 3.59^{\mathrm{a}}$ \\
\hline August & 55 & $1.38-8.35$ & $3.33 \pm 0.87^{\mathrm{b}}$ & 45 & $2.12-13.13$ & $7.12 \pm 2.87^{\mathrm{b}}$ \\
\hline September & 55 & $1.06-7.97$ & $3.34 \pm 1.21^{\mathrm{b}}$ & 45 & $4.89-17.15$ & $9.41 \pm 3.14^{\mathrm{a}}$ \\
\hline October & 54 & $0.98-4.58$ & $2.14 \pm 1.01^{\mathrm{c}}$ & 46 & $2.92-8.61$ & $5.37 \pm 2.29^{\mathrm{c}}$ \\
\hline November & 55 & $1.29-4.92$ & $2.38 \pm 0.85^{\mathrm{c}}$ & 45 & $1.21-8.71$ & $3.69 \pm 1.02^{\mathrm{d}}$ \\
\hline December & 53 & $1.11-8.81$ & $2.11 \pm 0.49^{\mathrm{d}}$ & 47 & $1.44-11.89$ & $4.56 \pm 0.46^{\mathrm{d}}$ \\
\hline
\end{tabular}

\section{Frequency occurrence of maturity stages of oocyte}

Eevery month, only 12 specimens were examined for this study. Early perinucleolus oocytes were found throughout the year except in February, March, April, July, August and September; recording the highest percentage in October. Late perinucleolar oocytes were also observed throughout the year except in April, July and August with the highest percentage in the non-spawning months. Yolk vesicle oocytes were observed throughout the study period except in January, February, March, April, July and September. Primary yolk globules started to appear from January to July except two months (March and May). 


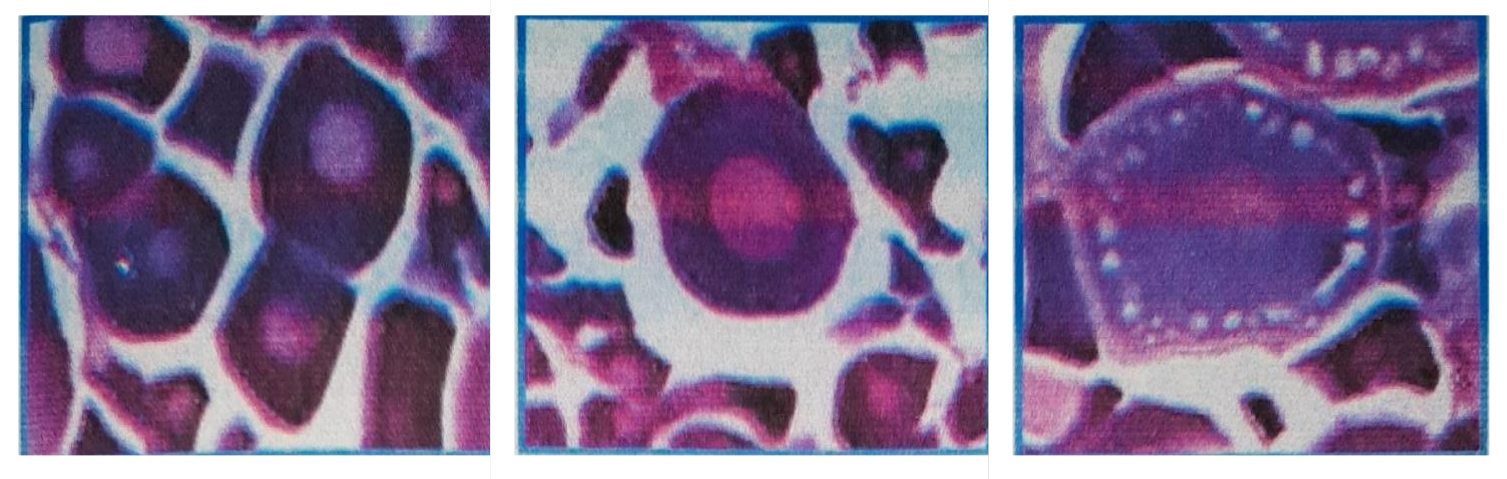

a.

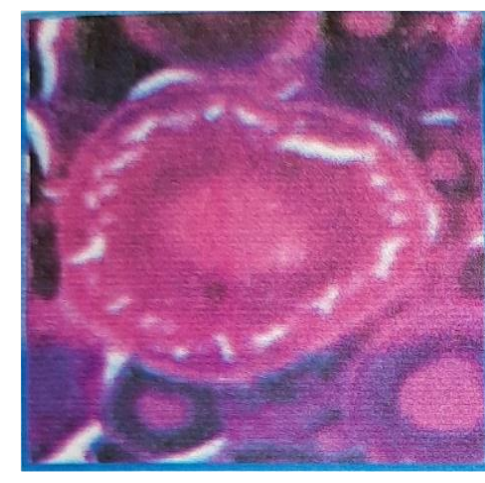

d.

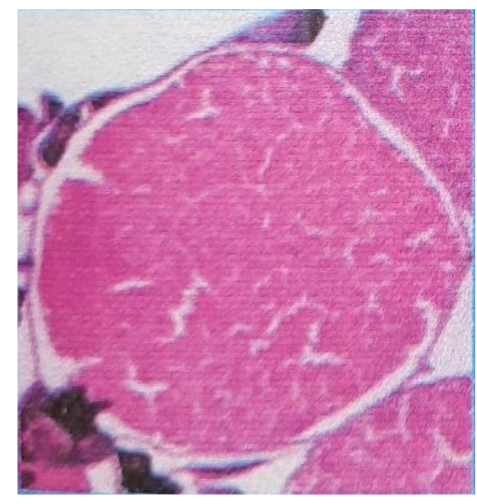

g. b.

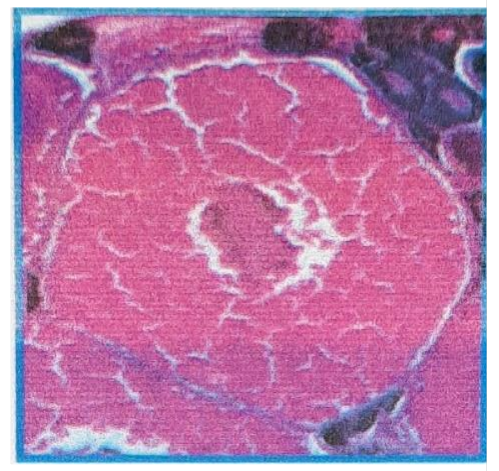

e.

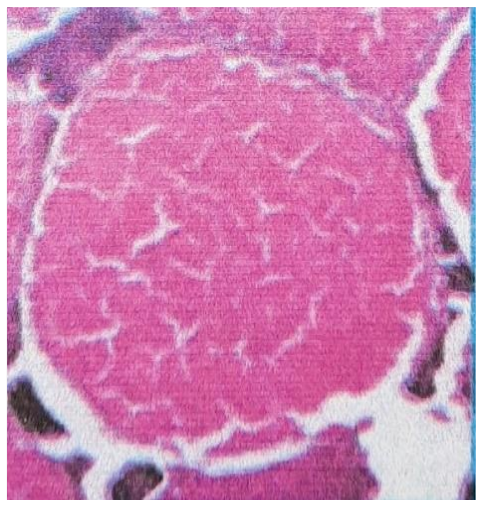

h.
C.

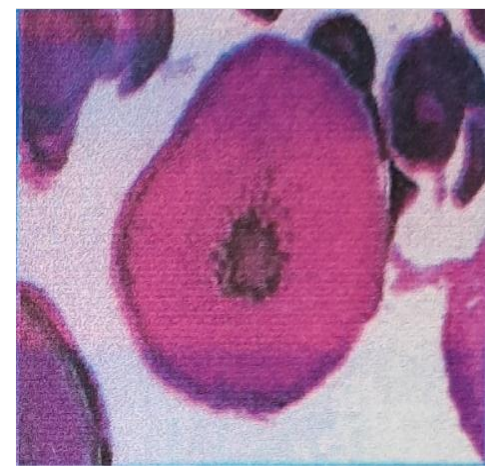

f.

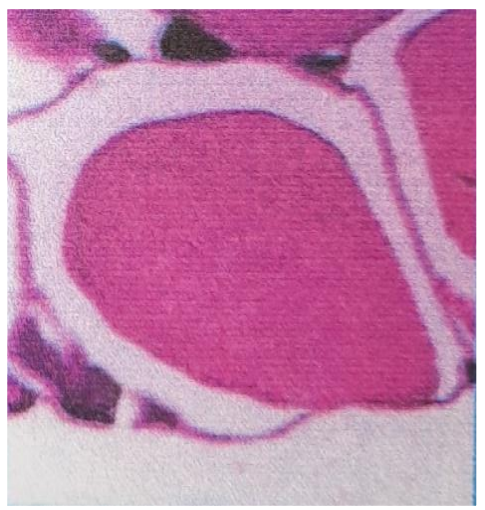

Fig. 1. Histological appearance of oocyte development of C. cachius

a.Early perinucleolus ; b. Late perinucleolus stage; c. Yolk vesicle stage; d. Primary yolk stage; e. Secondary yolk stage; f. Tertiary yolk stage; g. Migratory nucleus stage; h. Premature stage; i. Mature stage

Secondary yolk globules appeared from January to July except in May. Tertiary yolk globules were observed from February to October except in June. Migratory nucleolus oocytes were observed in January to December except in January, June, November and December. The mature oocytes appeared only from February to September except in 
June. The occurrence of mature oocytes appeared in February, maintaining peaked in April (45.77\%) and then decreased in May. There was no mature oocyte observed in June. Then, its occurrence increased in July; peaked in this month (55.25\%) and after that decreased in September. No mature oocyte was observed from October to January. This observation indicates two spawning seasons that lasted from February to May and from July to September (Table 3).

Table 3. Percent occurrences of the histological stages of ovaries of C. cachius

\begin{tabular}{llllllllll}
\hline Month & $\mathrm{EP}^{1}$ & $\mathrm{LP}^{2}$ & $\mathrm{YV}^{3}$ & $\mathrm{PY}^{4}$ & $\mathrm{SY}^{5}$ & $\mathrm{TY}^{6}$ & $\mathrm{MN}^{7}$ & $\mathrm{PM}^{8}$ & $\mathrm{M}^{9}$ \\
\hline January & 15.23 & 65.77 & & 2.50 & 3.75 & 12.75 & & & \\
\hline February & & 7.40 & & 7.16 & 15.34 & 22.77 & 5.33 & 9.75 & 32.25 \\
\hline March & & 5.50 & & & 4.50 & 20.50 & 17.84 & 21.66 & 30.50 \\
\hline April & & & & 1.75 & 7.00 & 25.75 & 7.50 & 12.23 & 45.77 \\
\hline May & 23.45 & 12.60 & 17.30 & & & & 14.75 & 12.80 & 19.20 \\
\hline June & & & 6.50 & 22.50 & 31.60 & 39.40 & & & \\
\hline July & & & & 3.70 & 4.50 & 5.35 & 11.45 & 20.75 & 55.25 \\
\hline August & & 8.65 & 2.00 & & & 32.75 & 14.50 & 29.60 & 12.25 \\
\hline September & & 4.10 & & & & 20.00 & 19.90 & 16.20 & 39.80 \\
\hline October & 47.50 & 23.75 & 10.00 & & & 6.25 & 12.50 & & \\
\hline November & 47.25 & 39.75 & 13.00 & & & & & & \\
\hline December & 25.75 & 57.50 & 14.33 & 2.42 & & & & & \\
\hline
\end{tabular}

1)Early Perinucleolus; 2)Late Perinucleolus;3)Yolk Vesicle; 4)Primary Yolk; 5)Secondary Yolk; 6)Tertiary Yolk; 7)Migratory Nucleus; 8)Pre-Maturation Stage; 9) Maturation Stage;

\section{Spawning frequency}

No hydrated eggs and postovulatory follicles were observed in the ovaries throughout the study period. Frequency distribution of egg diameter of ovaries from three different maturity stages (primary yolk, teriary yolk and premature) confirmed two distinct mode of oocyte at each case. The oocytes of the first mode were very small (0.11$0.17 \mathrm{~mm})$, while those of the second mode $(0.23-0.37 \mathrm{~mm})$ were considerably larger. Two sets of egg diameter assured that the $C$. cachius was single spawner because the second mode was to be shed together, while the first mode might be spawned in the next spawning season. Therefore, the present species was synchronous iteroparus which spawned once in a spawning season. 


\section{Fecundity and relationship with standard length and body weight}

From the spawning seasons, 30 female specimens were used for fecundity analysis. Fecundity estimates were 579 to 2914 eggs during the first spawning peak (from February to May) and 1163 to 2934 eggs during the second spawning peak (i.e. from July to September) in terms of standard length. The relationship between the fecundity and standard length was expressed as: $\mathrm{F}=0.0005 \mathrm{SL}^{3.76}\left(\mathrm{r}^{2}=0.827\right)$ during the first spawning season and $\mathrm{F}=0.0343 \mathrm{SL}^{2.809}\left(\mathrm{r}^{2}=0.897\right)$ during the second spawning season. The relationship between the fecundity and body weight was expressed as: $\mathrm{F}=949.2 \mathrm{BW}+46.00\left(\mathrm{r}^{2}=0.793\right)$ during the first spawning season and $\mathrm{F}=1380.7 \mathrm{BW}-$ $50.289\left(r^{2}=0.856\right)$ during the second spawning season.

\section{DISCUSSION}

Maturation of fish was subjected to the gonadosomatic index (GSI). The value of the GSI was at its maximum when the peak maturity occurred and then decreased when fish spent (Ahamed, 2012). The monthly changes in the GSI reflect the ovarian activity of fish and the GSI is a reliable tool to determine the peak spawning season (Amin et al., 2019). The GSI of $C$. cachius showed a clear pattern for two spawning peaks from February to May and from July to September for both sexes. The highest GSI value was found in July for males and females that could be the peak spawning period. Peaks of the GSI index value in July and April might be due to the completion of maturity, and subsequent steep fall in the index value clearly indicated alternatively the spawning and spent condition of fish. The spawning season of $C$. cachius is almost similar to other SIS (Small Indigenous Species) of Bangladesh as it has long spawning season and most of the spawning season of SIS fell within this period. Spawning ovaries began to increase in February and continued up to May and were suddenly absent in June. After that, these were again available from July to September. These results indicate two spawning seasons for C. cachius; lasted from February to May and from July to September.

This type of oocyte development was the most common strategy among teleosts (Dursun et al., 2013; Amin et al., 2019). In this study, oocytes maturation stages were classified into nine stages: early perinucleolus, late perinucleolus, yolk vesicle, primary yolk, secondary yolk, tertiary yolk, migratory nucleus, premature and mature stage. It was believed that, if samples during the spawning season were taken in late afternoon and evening, more advanced maturity stages could appear (Vladimir, 2000).

Based on the developmental stages and the GSI, the peak spawning season extended from April to July except in June. No fishes remained with mature stage in October. The authors refrained to compare the results as there was no literature available on this species. 
The spawning frequency may be determined on the basis of the occurrence or presence of postovulatory follicle; hydrated eggs (Hunter \& Macewicz, 1985; Rabie $\boldsymbol{e} t$ al., 2021) and the mode of frequency distribution of egg diameter (Almatar et al., 2004). In fact, the hydrated eggs and postovulatory follicles were not observed in ovaries. While, in case of multiple or serial spawner, fish may spawn more than once during a single spawning season and having multiple modes of oocytes diameter distributions (Matthew et al., 2017). Postovulatory follicles or hydrated eggs are the indications of a serial spawner (George, 1996). But, no postovulatory follicles or hydrated eggs was found in the current study.

The fecundity of $C$. cachius ranged from 579 to 2914 eggs during the first spawning peak (from February to May) and from 1163 to 2934 eggs during the second spawning peak (from July to September). Divipala et al., (2013) reported that the fecundity of $C$. fasciata ranged from 2669 to 4437. It shows somewhat similarity with the fecundity of $C$. cachius though it was an another species with the same genus.

Fish size, age, condition and types of species influenced the production and the number of eggs that was reported by Ahmed et al. (2012). It was also observed that the fecundity was less in some larger fish compared to some other smaller fish. This type of variation was also reported by different workers (Karim \& Hossain, 1972; Ahmed $\boldsymbol{e t}$ al., 2012). The study of Divipala et al. (2013) conducted on the Chela fasciata Silas and that of Sinha (1975) addressing the fecundity and the maturity of Puntius sarana detected a linear relationship between the fecundity and the standard length; findings that disagree with those of the present study.

\section{CONCLUSION}

Considering the GSI values, the analysis of external features of the ovaries and the observation of the ovarian histology showed that two spawning peaks of $C$. cachius exist in Bangladesh. The first peak occurs during February to May and the other during July to September, though egg diameter frequency distributions of different maturity stages confirmed it was a single spawner (synchronous iteroparus); spawning once in a spawning season. The study was conducted to obtain the fundamental knowledge on the reproductive parameters of the fish that would help evaluating the commercial potentialities of its stock, life history, culture practice and management.

\section{REFERENCES}

Afonso-Dias, I.; Reis, C. and Andrade, J.P. (2005). Reproductive aspects of Microchirus azevia (Risso, 1810) (Pisces: Soleidae) from the south coast of Portugal. Sci. Mar., 69(2): 275-283. https://doi.org/10.21608/ejabf.2012.2115. 
Ahamed, A.I. (2012). Reproductive biology of the tub gurnard Trigla lucerna (linnaeus, 1758), in the Libyan eastern coast of Mediterranean Sea. Egypt. J. Aquat. Biol. \& Fish., 16 (1): 95 -104. https://doi.org/10.1080/02705060.2011.633341.

Ahmed, Z.F.; Hossain, M.Y. and Ohtomi, J. (2011). Condition, length-weight and length-length relationships of the silver hatchet Chela, Chela cachius (Hamilton, 1822) in the Old Brahmaputra River of Bangladesh. J. Fresh. Ecol., 27 (1): 123-130. https://doi.org/10.1080/02705060.2011.633341.

Ahmed, Z.F.; Hossain, M.Y. and Ohtomi, J. (2012). Modeling the growth of silver hatchet Chela Chela cachius (Cyprinidae) from the old Brahmaputra River in Bangladesh using multiple functions. Zoolog. Stud., 51(3): 336-344.

Akter, Y.; Hosen, M.H.A.; Ahmed, Z.; Chhanda, M.S. and Shahriar, S.I.M. (2019). Impact of gonad weight on the length-weight relationships of river catfish (Clupisoma garua) in Bangladesh. Egyp. J. Aqua. Rese., 45: 375-379. https://doi.org/10.1016/j.ejar.2019.10.003.

Almatar, S.M.; Lone, K.P.; Abu-Rezq, T.S. and Yousef, A.A. (2004). Spawning frequency, fecundity, egg weight and spawning type of silver pomfret, Pampusa rgenteus (Euphrasen) (Stromateidae), in Kuwait waters. Appl. Ichthyol. 20:176188. https://doi.org/10.1111/j.1439-0426.2004.00546.x.

Amin, A.M.; Alaa, M.M.; Elhal, F.; Hafz, M.M.; Khouraiba and Mervat, A.M. A. (2019). Some biological aspect and gonads histology of Sepia savignyi (Blainville, 1827), in the Gulf of Suez, Egypt. Egypt. J. Aquat. Biol. \& Fish., 23(2): 43-54. https://doi.org/10.21608/ejabf.2019.32325.

Cech, G.; Molnar, K. and Szekely, C. (2012). Molecular genetic studies on morphologically indistinguishable Myxobolus spp. infecting cyprinid fishes, with the description of three new species, $M$. alvarezae sp. nov., M. sitjae sp. nov. and $M$. eirasianus sp. nov. Acta Parasitol., 57(4):354-366. https://doi.org/10.2478/s11686012-0045-2.

Chakraborty, B.K.; Mirza, Z.A. and Chakraborty, A. (2010). Reproductive cycle of the endangered pabda, ompok pabda (Hamilton-Bouchanan, 1822) in Bangladesh. Asian Fish. Scie., 23:301-320. https://doi.org/10.33997/j.afs.2010.23.3.003.

Divipala, I.; Mercy, T.V.A. and Nair, J.R. (2013). Reproductive biology of Chela fasciata Silas - an endemic ornamental barb of the Western Ghats of India. Indian J. Fish., 60(4): 41-45. 
Dursun, D.; Eronat, E.G.T.; Akalin, M. and Salman, M.A. (2013). Reproductive biology of pink cuttlefish Sepia orbignyana in the Aegean Sea (eastern Mediterranean). Turk. J. Zool., 37(5): 576-581. https://doi.org/10.3906/zoo-1209-22.

George, M.M.R. (1996). Contributions of the use of condition factor: Studies of Spanish sardine, Sardinops sagax, and Southern Pacific jack mackerel. Trachurus picturatus murphyi, off coast of Chile. ICES C. M. 1996/ H: 4., 15 pp.

Hamilton, F. (1822). An account of the fishes found in the river Ganges and its branches. Archibald Constable \& Co., Edinburgh and Hurst, Robinson \& Co., London., 405 pp. https://doi.org/10.5962/bhl.title.6897.

Hossain, M.A.R. and Wahab, M.A. (2010). The diversity of cypriniforms throughout Bangladesh: Present status and conservation challenges. In: Species Diversity and Extinction. Nova Science Publishers, Inc. New York, USA, pp.143-182.

Hunter, J.R. and Macewicz, B.J. (1985). Measurement of spawning frequency in multiple spawning fishes. NOAA Technical Report NMFS (National Marine Fisheries Service, 36: 79-94 pp.

Jasmine, S. and Molina, M.A. (2016). Reproductive biology of Mystus vittatus (Bloch, 1794) in the Padma River, Bangladesh. Inter. J. Fish. \& Aqua. Stud., 4(5): 666-669.

Karim, M.A. and Hossain, A. (1972). Studies on the biology of Mastecembelus pancalus (spiny eel, Ham.) in artificial ponds. Part II. Sexual maturity and fecundity. Bangladesh J. Biol. and Agril. Sci., 1(2): 15-18.

Lubzensa, E.; Graham Y.; Julien, B. and Joan, C. (2010). Oogenesis in teleosts: How fish eggs are formed. Gen. \& comp. Endoc., 165:367-389. https://doi.org/10.1016/j.ygcen.2009.05.022.

Matthew, K.S.; Matthew, J.A.; Jennifer, J.W.; Jason, A.W.; Shipley, J.B. and Gregory, W.S. (2017). A comparison of size structure, age, and growth of red snapper from artificial and natural habitats in the Western Gulf of Mexico. Trans. Ameri. Fish. Soc., 146 (4):762-777. https://doi.org/10.1080/00028487.2017.1308884.

Mojumder, N.; Saha, D.; Utsa, S.; Maruf, M.K.K. and Paul, S. K. (2020). Biology of the endangered queen loach (Botia dario) collected from wild sources in Bangladesh. AACL Bioflux, 13(5):2599-2609.

Mondal, S.; Wahab, M.A.; Barman, B.K. and Hossain, M.M.H. (2019). Advances in bioresearch reproductive biology of flying barb, darkina, Esomus danricus with some related characteristics. Adv. Biores., 10 (2): 68-81. 
Rabie, G., Ahlem, M. and Mehanna S.F. (2021). Reproductive dynamics of the redbelly tilapia (Tilapia zillii Gervais, 1848) in Ayata lake as a Ramsar site in southeastern Algeria. Egypt. J. Aquat. Biol. \& Fish., 25(2): 253-265. https://doi.org /10.21608/ejabf.2021.163880.

Rahman, M.H. and Tachihara, K. (2005). Reproductive biology of Sillago aeolus in Okinawa Island, Japan. Fisheries Sci., 71: 122-132. https://doi.org/10.1111/j.14442906.2005.00939.x.

Saha, N.; Rakib, M.H.; Mredul, M.M.H.; Rahman, M.A. and Ahamed, F. (2021). Life history traits of the gangetic scissortail rasbora, Rasbora rasbora (Hamilton, 1822) in the payra river, southern Bangladesh. Jord. J. Biol. Scie., 14 (1): 129 -135.

Santos, R.S.; Hawkins, S.; Morteino, L.R.; Alves, M. and Isidro, E.J. (1995). Case studies and reviews. Marine research, resources and conservation in the A20. Res. Aquat. Conserv, Mar. Freshwat. Ecosyst. 4: 311-354. https://doi.org/10.1002/ aqc. 3270050406.

Sinha, M. (1975). Observation on the biology of Puntius sarana (Hamilton 1822) of loni reservoir (Madhya Pradesh). J. Inland Fish. Soc. India., 7:49-57.

Tan-Fermin, J.D.; Ljiri, S.; Ueda, H.; Adachi, S. and Yamauchi, K. (1997). Ovarian development and serum steroid hormone profiles in hatchery-bred female catfish Clarias macrocephalus (Gunther) during an annual reproductive cycle. Fish. Sci., 63(6): 867-872. https://doi.org/10.2331/fishsci.63.867.

Vladimir, P.G. (2000). Age, growth and reproduction of yellowbelly threadfin bream Nemiterus bathybius in Kagoshima Bay, Southern Japan. Ph. D. Thesis, Kagoshima University, Japan. pp.30-58. 